\title{
Flower Bud Induction of Sweet Orange Trees [Citrus sinensis (L.) Osbeck]: Effect of Low Temperatures, Crop Load, and Bud Age
}

\author{
Juan I. Valiente ${ }^{1}$ and L. Gene Albrigo ${ }^{2}$ \\ Horticultural Sciences, University of Florida, IFAS, Citrus Research and Education Center, 700 Experiment \\ Station Road, Lake Alfred, FL 33850
}

\begin{abstract}
AdDITIONAL INDEX wORDs. flowering intensity, reproductive growth, phenology, humid subtropics, gibberellins, carbohydrates
Aвstract. Citrus flowering is a complex phenological process influenced by a number of interacting factors. Low winter temperatures are recognized as an important factor, but the flowering response has not been quantified under Variable natural conditions. A study was conducted to monitor the flower bud induction response of 'Valencia' and 'Hamlin' sweet orange trees [Citrus sinensis (L.) Osbeck] to naturally occurring winter weather conditions during the 1999 and 2000 seasons. The flowering response was quantified and related to shoot age, bud position along the shoot, local weather information, and crop load status. Results indicate that buds on previous summer shoots developed 2.52 and 3.59 to 1 flower on spring shoots, for 'Hamlin' and 'Valencia', respectively. In addition, buds at apical positions produced more flowers than buds located far from the apex. These basal positions buds required higher induction levels. Under Florida conditions, greater accumulation of hours of temperatures 11 to $15{ }^{\circ} \mathrm{C}$ increased floral intensity by the combined effect on the number of sprouting buds with reproductive growth and the number of flowers per flowering bud. Some statistical analyses indicated that high winter temperatures reduced flowering in 'Valencia' and 'Hamlin' oranges. The presence of fruit consistently reduced reproductive response for both cultivars. Crop load reduced flowering by an average of $41.5 \%$ compared to no crop and varied by cultivar. A discussion on the different induction requirements as well as on the differential effect of crop load on flowering by cultivar is presented.
\end{abstract}

The flowering process in citrus consists of several discrete phases: flower bud induction, bud differentiation, and anthesis. The induction process is associated with environmental factors and results in the commitment of meristematic cells to form reproductive structures. Under subtropical conditions, citrus flowering occurs primarily during the spring following the inductive winter season (GarcíaLuis et al., 1995a; Monselise and Halevy, 1964; Simanton, 1969). During winter, low-temperature conditions cause the inactivity of buds while inducing them to flower (Reuther et al., 1973). Once induced, the release of the stress by higher temperatures triggers the beginning of reproductive growth (Cassin et al., 1969), provided that other conditions are not limiting.

Floral differentiation involves the anatomical and morphological transition of vegetative meristems to floral meristems (Davenport, 1990). In citrus, the differentiation of floral organs begins at the first stages of bud swelling and sprouting. The time of initiation of differentiation varies by citrus cultivar and environmental conditions (Abbott, 1935). Following differentiation, the rate of flower bud development depends on temperature and the number of flowers differentiating (Guardiola, 1997; Moss, 1973a). Anthesis occurs after the induction and differentiation processes have been completed, usually when warmer springtime conditions exist (Bellows and Morse, 1986; Lovatt et al., 1984).

Ambient temperature not only has a direct effect on induction and differentiation but also affects flowering date and intensity (Cassin et al., 1969; García-Luis et al., 1992). Sustained periods of

Received for publication 12 June 2003. Accepted for publication 27 Oct. 2003. This research was supported by the Florida Agricultural Experiment Station and was partially funded by a grant from the Florida Citrus Production Research Advisory Council (FCPRAC) and reports part of the PhD dissertation work of the senior author and was approved for publication as Journal Series No. N-02357.

${ }^{1}$ Assistant professor, Instituto Tecnológico y de Estudios Superiores de Monterrey, Campus Monterrey, Dept. Centro de Estudios del Agua, Ave. Eugenio Garza Sada 2501, Aulas 7-316, Col. Tecnológico, 64849 Monterrey, N.L.

2Professor and corresponding author; e-mail albrigo@1al.ufl.edu. low temperature in winter will produce a later anthesis by delaying initiation of differentiation and reducing the subsequent growth rate of the bud (Lomas and Burd, 1983). High daytime temperatures during floral differentiation shorten development time and advance date of anthesis (Moss, 1973a; Valiente and Albrigo, 2002). As for flower intensity, greater accumulation of hours of low temperature increases floral induction, thus increasing number of flowers per tree, number of flowers per node, and sprouting (Poerwanto and Inoue, 1990). As hours of low temperature accumulate, bud sprouting shifts from vegetative (with no flowers) to mixed (flowers and leaves) to mostly reproductive (leafless with at least one flower) (Moss, 1969). High temperatures during sprouting are reported to increase inflorescence leafiness and to inhibit flowering.

The presence of fruit located at the apex of branches has an inhibitory effect on the sprouting of new shoots and on the expression of the nature (vegetative or reproductive) of basipetal lateral buds (García-Luis et al, 1986; Goldschmidt and Monselise, 1972; Koshita et al., 1999; Moss, 1969; Reuther, 1973). The presence of fruit does not exert a strong inhibitory effect on the growth of shoots from neighboring branches. Fruit diminish the proportion of buds that are able to sprout on the spring growth (García-Luis et al., 1995b). The inhibitory effect of crop load on sprouting and on vegetative and reproductive development seems to be related to hormonal changes (mainly GA) and carbohydrate competition (Goldschmidt et al., 1985). No attempts appear to have been made to quantitatively characterize the inhibitory effects of crop load on flower induction.

Bud or shoot age and position along the shoot also affect bud sprouting and flowering. Only shoots younger than one year old contribute significantly to the formation of spring growth (Guardiola, 1981; Guardiola et al., 1977; Lovatt et al., 1984). Once the shoots are mature, the proportion of buds sprouting in spring decreases with increasing shoot age. García-Luis et al. (1995b) reported that summer shoots developed more vegetative buds than generative 
buds. Also, younger buds (nearer shoot apex) produce more flowers than older buds (Guardiola, 1981). Few reports disclose the position within the canopy of different aged stems, thus it is not possible to determine whether heaviest flowering is associated with canopy position of stems or only with shoot or bud age (Krajewski and Rabe, 1995).

Although winter low temperatures increase citrus flowering (Furr et al., 1947; Moss, 1969), the effects of natural winter temperatures on phenology have not been quantified. This is particularly important in Florida, where winter time accumulation of hours of inductive temperatures $\left[<20^{\circ} \mathrm{C}\right.$ (Moss, 1976) $]$ can vary from 712 to $1474 \mathrm{~h}$ per year [(analysis of Florida's historic climatological data, Valiente, 2001)] and may explain the great variability in flowering intensity from year to year.

Due to the nature of field citrus trees, monitoring their flower bud induction is complicated. Girdling and defoliation is the primary technique available for induction monitoring of field citrus trees (Ayalon and Monselise, 1960; Furr and Armstrong, 1956; Furr et al., 1947). This method is based on the concept that the low temperature induction stimulus is perceived at the leaves and is translocated through the phloem. Defoliation prevents the further perception of the inductive stimulus, and girdling prevents the stimulus to reach the buds above the girdle. This technique is widely accepted as the primary means for induction monitoring regardless of some identified drawbacks. Among them, the facts that some induction stimulus might also be perceived at the bud itself (García-Luis et al., 1992; Tisserat et al., 1990), that girdling and defoliation is restricted to phloem transportable factors (Altman and Goren, 1974), and that it may have an effect on the percentage of sprouting buds.

Therefore, the objectives of this study were to quantify and statistically characterize the reproductive phenological responses of field citrus trees to local weather information (induction level), shoot age, bud position along the shoot, and crop load status. These factors are known to affect citrus flower bud induction, but are not adequately quantified nor have they been evaluated in an integrated way, particularly in the field.

\section{Materials and Methods}

This study was conducted at two locations near Lake Alfred, Florida during the 1998-1999 and 1999-2000 seasons (hereafter called the 1999 and 2000 seasons for the year of flowering, respectively). The first location was a commercial grove containing mature 15-year-old 'Hamlin' sweet orange trees [Citrus sinensis (L.) Osbeck] grafted on 'Carrizo' citrange [Citrus sinensis (L.) Osbeck $\times$ Poncirus trifoliata (L.) Raf.] rootstock. In this location, 14 and 15 healthy, uniform trees were selected for the first and second year of study, respectively. The second location consisted of 6-year-old 'Valencia' sweet orange trees [Citrus sinensis (L.) Osbeck] grafted on 'Swingle' citrumelo [Citrus paradisi Macf. $\times$ Poncirus trifoliata (L.) Raf.] rootstock. For this location, a total of 14 and 16 trees were used for the first and second year of study, respectively. Both locations were under commercial horticultural practices for the region that included periodic winter irrigation.

Experimental units consisted of pairs of branches holding two different levels of crop load. Branch pairs were selected in October after the summer flush was complete. Late summer and fall shoots were not selected. Paired branches of similar size (2- to 3-cm base diameter) were selected from the same tree location (quadrant and height), but differing in natural crop load (with and without developing fruit). Branches with crop load had an average of 5.2 and 3.1 fruit per branch for the 'Hamlin' or 'Valencia' branches, respectively. No fruit were removed to adjust crop load. A number of individual shoots were selected and tagged according to their age ( 3 to 5 spring or summer each) on all the branches.

This study was conducted using a randomized block design for the induction treatments with nested crop load treatments. Each induction treatment was replicated six times down a row of trees. Branch pairs were assigned to each treatment and the repetition of treatments within the same tree or the repetition of spatial locations of the same treatment in different trees was avoided. An average of 4.8 pairs of branches ( 4 to 7 ) were selected in each 'Hamlin' tree, while for 'Valencia', this average was of 4.7 (3 to 7) branch pairs in each tree.

For the induction treatments, experimental units were exposed to naturally occurring temperature conditions and were subjected to treatments to interrupt induction at an array of timings. Starting 1 Nov., induction was interrupted twice monthly on different sets of paired branches by girdling and defoliation. Induction treatments were identified by the date of interruption of induction on the branches. For both years and cultivars, one set of branches was left without girdling and defoliation to complete their normal flowering cycle (control branches). 'Hamlin' trees were exposed

Table 1. Cumulative number of hours from 1 Oct. up to each treatment date in $5^{\circ} \mathrm{C}$ increments for the $1998-1999$ and $1999-2000$ seasons.

\begin{tabular}{|c|c|c|c|c|c|c|c|c|c|}
\hline \multicolumn{2}{|c|}{ Treatment date } & $<0$ & $0-5$ & $6-10$ & $11-15$ & $16-20$ & $21-25$ & $26-30$ & $>30$ \\
\hline$\overline{1}$ & 13 Nov. 1998 & 0 & 0 & 0 & 0 & 123 & 310 & 261 & 98 \\
\hline 2 & 17 Nov. 1998 & 0 & 0 & 1 & 31 & 230 & 434 & 331 & 102 \\
\hline 3 & 4 Dec. 1998 & 0 & 0 & 1 & 45 & 342 & 600 & 441 & 108 \\
\hline 4 & 18 Dec. 1998 & 0 & 1 & 18 & 91 & 456 & 695 & 503 & 108 \\
\hline 5 & 5 Jan. 1999 & 0 & 8 & 51 & 160 & 648 & 788 & 543 & 108 \\
\hline 6 & 19 Jan. 1999 & 7 & 28 & 100 & 228 & 748 & 854 & 568 & 108 \\
\hline 7 & 2 Feb. 1999 & 7 & 28 & 101 & 266 & 881 & 967 & 619 & 108 \\
\hline 8 & 16 Feb. 1999 & 7 & 32 & 124 & 304 & 1019 & 1046 & 673 & 108 \\
\hline Control & 3 Mar. 1999 & 7 & 44 & 177 & 384 & 1114 & 1116 & 698 & 108 \\
\hline 1 & 3 Nov. 1999 & 0 & 0 & 3 & 35 & 113 & 410 & 192 & 40 \\
\hline 2 & 18 Nov. 1999 & 0 & 0 & 14 & 83 & 277 & 498 & 241 & 40 \\
\hline 3 & 3 Dec. 1999 & 0 & 9 & 35 & 135 & 425 & 597 & 272 & 40 \\
\hline 4 & 16 Dec. 1999 & 0 & 9 & 48 & 180 & 566 & 685 & 297 & 40 \\
\hline 5 & 3 Jan. 2000 & 0 & 20 & 99 & 301 & 742 & 738 & 318 & 40 \\
\hline 6 & 18 Jan. 2000 & 0 & 20 & 131 & 383 & 878 & 807 & 359 & 40 \\
\hline 7 & 4 Feb. 2000 & 4 & 50 & 220 & 503 & 993 & 848 & 368 & 40 \\
\hline Control & 1 Mar. 2000 & 4 & 59 & 283 & 666 & 1178 & 996 & 447 & 40 \\
\hline
\end{tabular}


Table 2. Percent distribution of flowers by bud position along the shoot and the relative number of flowers in summer and spring shoots for 'Hamlin' and 'Valencia' cultivars by combining data for the control branches of the 1999 and 2000 seasons.

\begin{tabular}{|c|c|c|c|c|}
\hline \multirow[b]{2}{*}{$\begin{array}{l}\text { Bud } \\
\text { position }\end{array}$} & \multicolumn{2}{|c|}{ Hamlin } & \multicolumn{2}{|c|}{ Valencia } \\
\hline & $\begin{array}{c}\text { Spring } \\
\text { shoots }(\%)\end{array}$ & $\begin{array}{c}\text { Summer } \\
\text { shoots }(\%)\end{array}$ & $\begin{array}{c}\text { Spring } \\
\text { shoots }(\%)\end{array}$ & $\begin{array}{c}\text { Summer } \\
\text { shoots }(\%)\end{array}$ \\
\hline 1 (apex) & 37.6 & 23.8 & 39.7 & 31.1 \\
\hline 2 & 21.1 & 20.3 & 21.4 & 21.7 \\
\hline 3 & 21.3 & 20.1 & 23.4 & 21.5 \\
\hline 4 & 8.1 & 14.3 & 11.3 & 11.8 \\
\hline 5 & 5.6 & 8.7 & 2.4 & 6.7 \\
\hline 6 & 2.9 & 5.5 & 1.5 & 3.1 \\
\hline 7 & 1.4 & 3.2 & 0 & 1.7 \\
\hline 8 & 1.7 & 2.1 & 0.3 & 0.5 \\
\hline 9 & 0.3 & 0.8 & 0 & 0.7 \\
\hline 10 & 0 & 1.2 & 0 & 1.2 \\
\hline Relative number of flowers per shoot & 1 & 2.5 & 1 & 3.6 \\
\hline
\end{tabular}

to a total of 9 and 8 induction treatments during the 1999 and 2000 seasons, respectively; while 'Valencia' trees were exposed to 9 and 7 induction treatments for the same seasons. In 2000, fewer induction treatments were administered due to earlier bud sprouting.

Data collected from each branch included: cultivar, induction treatment, crop load status, and number of shoots able to bear flowers. Bud sprouting data included total number of sprouting buds separated by their reproductive and vegetative nature (not presented here, see Valiente, 2001). Flowering data from each branch and from different age shoots included total number of flowers per branch, and flowers per inflorescence by position of the bud along the shoot. The sprouting bud in the leaf axis position nearest the apex was considered to be in Position 1, the bud in the nearest leaf axis following this first position was considered to be Position 2, and so on.

EFFECT OF SHOOT AGE (SUMMER VS. SPRING) ON FLORAL DISTRIBUTION. Floral distribution by shoot age was obtained using flowering data from tagged spring or summer shoots of control branches of both cultivars. Data collected from each shoot included total number of flowers per bud and their distribution by position along the shoot. Percentages of the total number of flowers coming from each shoot age, as well as their distribution along the shoot were calculated.

EFFECTS OF INDUCTION LEVELS AND CROP LOAD TREATMENTS ON PHENOLOGICAL RESPONSE. Analyses of variance were used to determine the effect of induction and crop load treatments on the phenological response of 'Valencia' and 'Hamlin' trees during both seasons. Significance values for all analyses of variance were set at $P \leq 0.05$ for significant (*), and $P \leq 0.01$ for highly significant (**). Values above $P>0.05$ were considered nonsignificant (NS).

The effects of induction levels and crop load treatments on the floral distribution by bud position along the shoot were determined using analyses of variance. These analyses used the total number of flowers on each position divided by the number of shoots able to bear flowers (flowers per shoot).

EFFECT OF WEATHER ON THE PHENOLOGICAL RESPONSE OF ' $V$ ALENCIA' AND 'HAMLIN' TREES. Local weather information from October to March of both seasons was obtained from a nearby weather station. Temperature records were stratified into 5-degree increments and the cumulative number of hours within each range was tabulated from 1 Oct. up to the date of each interruption of induction (Table 1).

Phenological variables were related to local weather data using linear stepwise multiple regression analysis procedures at 0.1 significance level (SAS, NC State Version 8.2). Flower buds per shoot, flowers per shoot, and flowers per flowering bud (inflores- cence) were used as dependent variables, while the cumulative number of hours at each temperature range and rainfall levels were used as independent variables, and crop load status was used as an independent parametric variable $(0$ or 1$)$.

\section{Results}

EFFECT OF BUD POSITION AND SHOOT AGE (SUMMER VS. SPRING) ON FLORAL DISTRIBUTION. On control branches at natural induction levels, 'Hamlin' buds in Positions 1 through 3 accounted for $64.2 \%$ and $80 \%$ of the total flowers for summer and spring shoots, respectively, for 1999 and 2000 combined (Table 2). 'Valencia'buds on control branches in the same positions accounted from $74.3 \%$ and $84.5 \%$ of the total flowers of the corresponding shoot ages. Summer shoots developed more flowers than spring shoots for both cultivars and seasons (Table 2). Combining both seasons, the relative number of flowers per shoot developed on summer shoots of 'Hamlin' trees was 2.5 to 1 flower on spring shoots. Similarly, summer shoots of 'Valencia' developed 3.6 flowers per shoot for each flower developed on spring shoots.

EFFECTS OF INDUCTION LEVELS AND CROP LOAD TREATMENTS ON PHENOLOGICAL RESPONSE. As the winter progressed, increased induction levels generally caused an increase in the number of flowers per shoot (Figs. 1 and 2). In 'Hamlin' there was one treatment per year in which buds that had been exposed to more inductive conditions developed fewer flowers than those exposed to lower inductive conditions (Fig. 1, Treatment 5 in 1999 and 4 in 2000).

The distribution of flowers by position along the shoot (for summer and spring shoots) for both cultivars showed a marked apical dominance. At all induction levels, buds in more apical positions developed more flowers than buds farther from the apex. At the lowest induction levels floral development occurred on some shoots exclusively in buds at the apical position. Athigher induction levels, floral intensity increased by more flowers developing at the apical positions and by the flowering of buds farther from the apex. Basal positions only developed flowers at the highest induction levels. At all induction levels and for both cultivars, the presence of crop load significantly reduced the flowering response. Over both seasons and cultivars for control limbs, crop load reduced flowering response from $17.1 \%$ to $65.1 \%$, average $41.5 \%$ (calculated from data displayed in Figs. 1 and 2).

EFFECT OF WEATHER ON THE PHENOLOGICAL RESPONSE OF ' ${ }^{\text {VALEN- }}$ CIA'AND 'HAMLIN' TREES. The results of stepwise multiple regression analyses relating flowering phenological parameters (flowering buds per shoot, flowers per flowering bud, and flowers per shoot) 
Valencia 1999 No Crop Loat

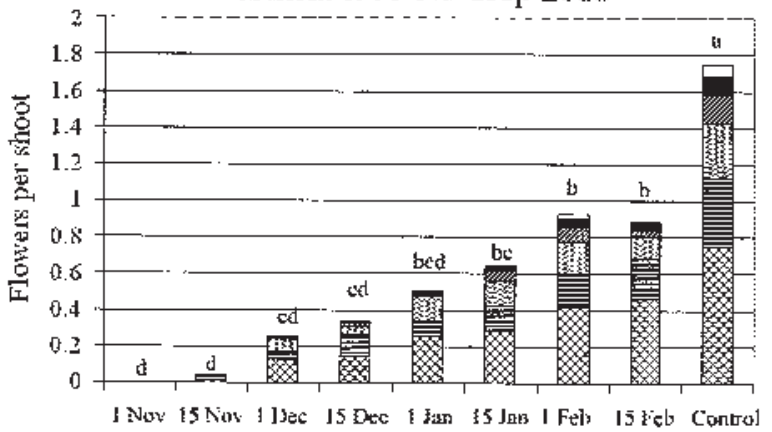

Valencia 2000 No Crop Load

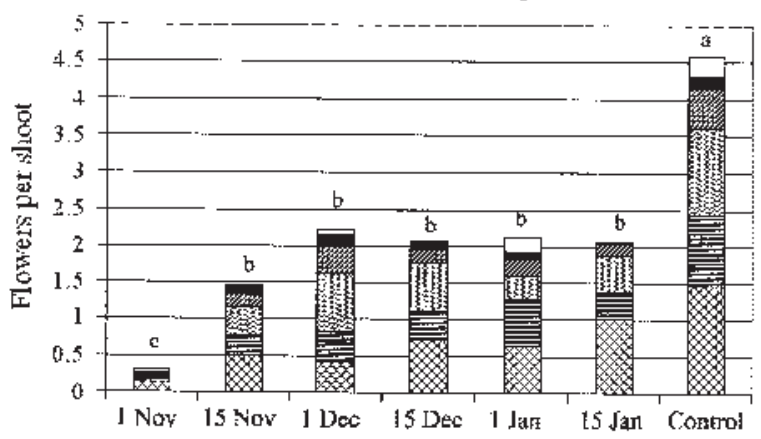

Date of Intereuption of Induction
Valencia 1999 With Crop Load

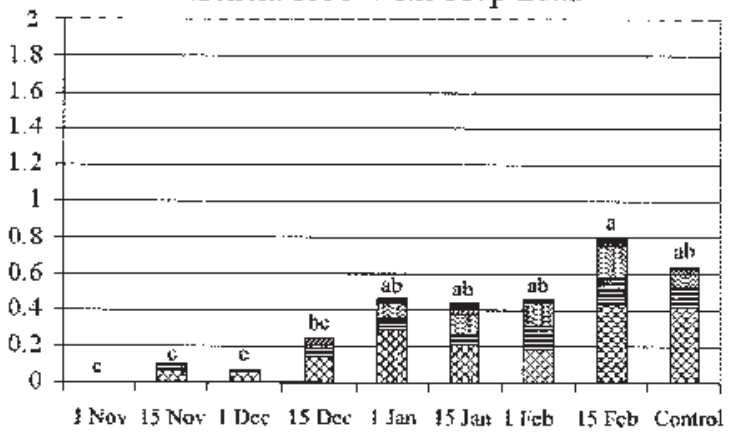

Falenera 2000 With Crop Load

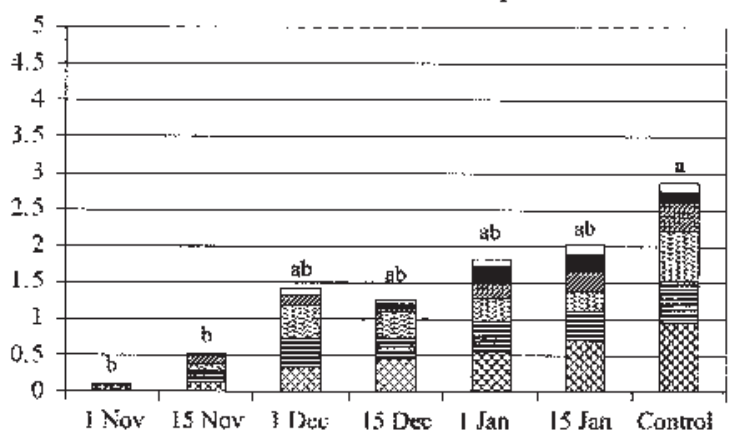

Date of hiterruption of Induction
ㄷ. Pos, 36

- Pos 5

Pos. 4

圈 Pos, 3

目 Pos. 2

웅 Pos. 1 (apex)

Fig. 1. Effects of different induction levels and crop load treatments on the distribution of flowers by bud position along the shoot of 'Hamlin' sweet orange trees during the 1999 and 2000 seasons. Data are presented as flowers per shoot.

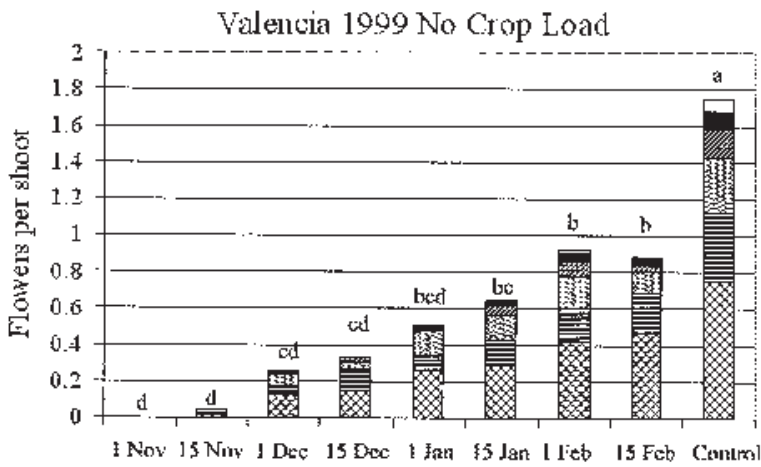

Falencia 3000 No Crop Loat

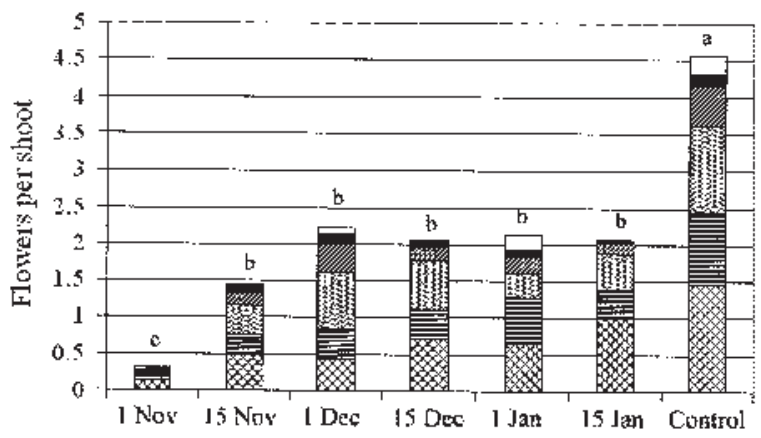

Date of Interruption of Induction

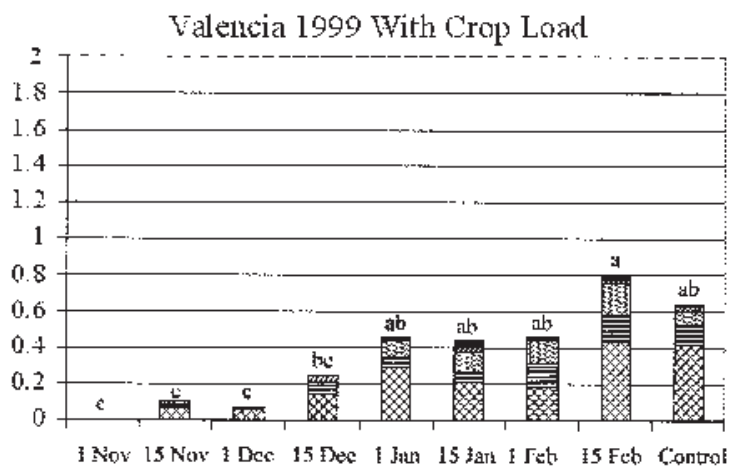

Falencia 2000 Witly Crop Lad

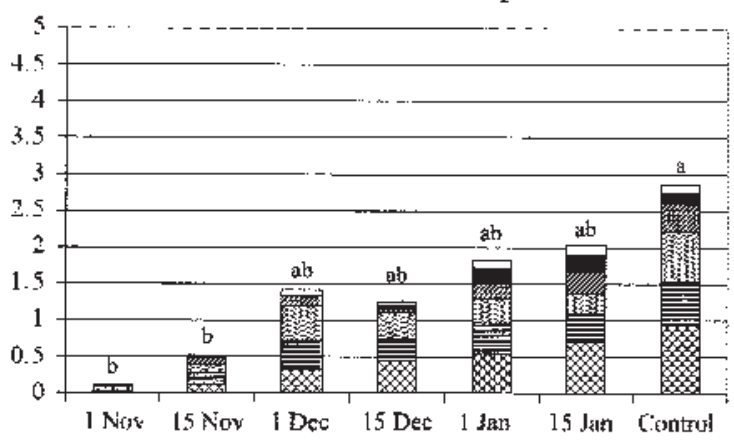

Date of Interruption of lnduction $\square$ Pos $>6$

- Pos. 5

图 Pos, 4

图 jos. 3

同 Pos. 2

응 Pos. 1 (aprex)

Fig. 2. Effects of different induction levels and crop load treatments on the distribution of flowers by bud position along the shoot of 'Valencia' sweet orange trees during the 1999 and 2000 seasons. Data are presented as flowers per shoot. 
Table 3. Results of stepwise multiple regression analyses relating flowering phenological parameters of 'Hamlin' trees, as dependent variables, to temperature data (in the form of the total number of hours $(\mathrm{H})$ in ranges of $5{ }^{\circ} \mathrm{C}$ increments) and crop load status, as independent variables for the combined data of the 1999 and 2000 seasons.

\begin{tabular}{|c|c|c|c|c|c|c|c|c|}
\hline \multirow[b]{3}{*}{$\begin{array}{l}\text { Dependent } \\
\text { variable }\end{array}$} & \multicolumn{8}{|c|}{ Hamlin } \\
\hline & \multicolumn{4}{|c|}{ All data } & \multicolumn{4}{|c|}{ No controls } \\
\hline & $\begin{array}{c}\text { Independent } \\
\text { variable }\end{array}$ & $\begin{array}{c}\text { Parameter } \\
\text { estimate }\end{array}$ & $P$ & $R^{2}$ & $\begin{array}{c}\text { Independent } \\
\text { variable }\end{array}$ & $\begin{array}{c}\text { Parameter } \\
\text { estimate }\end{array}$ & $P$ & $R^{2}$ \\
\hline \multirow[t]{4}{*}{ Flowering buds per shoot } & Model & & $* *$ & 0.79 & Model & & $* *$ & 0.70 \\
\hline & Intercept & 0.6851 & $* *$ & & Intercept & 0.67276 & $* *$ & \\
\hline & H $11-15$ & 0.00236 & $* *$ & 0.64 & H $11-15$ & 0.00231 & $* *$ & 0.53 \\
\hline & Fruit & -0.40742 & $* *$ & 0.15 & Fruit & -0.3742 & $* *$ & 0.17 \\
\hline \multirow[t]{4}{*}{ Flowers per flowering bud } & Model & & $*$ & 0.18 & Model & & $*$ & 0.11 \\
\hline & Intercept & 2.6063 & $* *$ & & Intercept & 2.74096 & $* *$ & \\
\hline & H $11-15$ & 0.00075 & $*$ & 0.10 & Fruit & -0.31345 & $*$ & 0.11 \\
\hline & Fruit & -0.29261 & $*$ & 0.08 & & & & \\
\hline \multirow[t]{6}{*}{ Flowers per shoot } & Model & & $* *$ & 0.73 & Model & & $* *$ & 0.70 \\
\hline & Intercept & 1.9825 & $* *$ & & Intercept & 3.49221 & $* *$ & \\
\hline & H $11-15$ & 0.00714 & $* *$ & 0.57 & $\mathrm{H}<0$ & 0.15538 & $*$ & 0.04 \\
\hline & Fruit & -1.35771 & $* *$ & 0.16 & H $11-15$ & 0.00389 & $* *$ & 0.43 \\
\hline & & & & & $\mathrm{H}>30$ & -0.01672 & $* *$ & 0.04 \\
\hline & & & & & Fruit & -1.23039 & $* *$ & 0.19 \\
\hline
\end{tabular}

Table 4. Results of stepwise multiple regression analyses relating flowering phenological parameters of 'Valencia' trees, as dependent variables, to temperature data (in the form of the total number of hours $(\mathrm{H})$ in ranges of $5{ }^{\circ} \mathrm{C}$ increments) and crop load status, as independent variables for the combined data of the 1999 and 2000 seasons.

\begin{tabular}{|c|c|c|c|c|c|c|c|c|}
\hline \multirow[b]{3}{*}{$\begin{array}{l}\text { Dependent } \\
\text { variable }\end{array}$} & \multicolumn{8}{|c|}{ Valencia } \\
\hline & \multicolumn{4}{|c|}{ All data } & \multicolumn{4}{|c|}{ No controls } \\
\hline & $\begin{array}{l}\text { Independent } \\
\text { variable }\end{array}$ & $\begin{array}{c}\text { Parameter } \\
\text { estimate }\end{array}$ & $P$ & $R^{2}$ & $\begin{array}{c}\text { Independent } \\
\text { variable }\end{array}$ & $\begin{array}{l}\text { Parameter } \\
\text { estimate }\end{array}$ & $P$ & $R^{2}$ \\
\hline \multirow[t]{5}{*}{ Flowering buds per shoot } & Model & & $* *$ & 0.88 & Model & & $* *$ & 0.85 \\
\hline & Intercept & 0.80466 & $* *$ & & Intercept & 0.74775 & $* *$ & \\
\hline & H $11-15$ & 0.00187 & $* *$ & 0.62 & H $11-15$ & 0.00196 & $* *$ & 0.49 \\
\hline & $\mathrm{H}>30$ & -0.00687 & $* *$ & 0.22 & $\mathrm{H}>30$ & -0.0066 & $* *$ & 0.34 \\
\hline & Fruit & -0.18159 & $* *$ & 0.04 & Fruit & -0.1189 & $*$ & 0.03 \\
\hline \multirow[t]{6}{*}{ Flowers per flowering bud } & Model & & $* *$ & 0.62 & Model & & $* *$ & 0.62 \\
\hline & Intercept & 1.00422 & $* *$ & & Intercept & -0.000475 & NS & \\
\hline & H $11-15$ & 0.00291 & $* *$ & 0.54 & H 6-10 & -0.02275 & $* *$ & 0.06 \\
\hline & Fruit & -0.38948 & $* *$ & 0.08 & H $11-15$ & 0.01015 & $* *$ & 0.40 \\
\hline & & & & & H $21-25$ & 0.00151 & $*$ & 0.07 \\
\hline & & & & & Fruit & -0.36371 & $* *$ & 0.09 \\
\hline \multirow[t]{6}{*}{ Flowers per shoot } & Model & & $* *$ & 0.84 & Model & & $* *$ & 0.83 \\
\hline & Intercept & 1.65533 & $* *$ & & Intercept & 1.49333 & $* *$ & \\
\hline & H $11-15$ & 0.00756 & $* *$ & 0.59 & $\mathrm{H}<0$ & -0.07251 & $*$ & 0.49 \\
\hline & Н $26-30$ & -0.00413 & $* *$ & 0.20 & H $16-20$ & 0.002 & $* *$ & 0.28 \\
\hline & Fruit & -0.54723 & $* *$ & 0.04 & $\mathrm{H}>30$ & -0.01745 & $* *$ & 0.04 \\
\hline & & & & & Fruit & -0.33831 & $* *$ & 0.02 \\
\hline
\end{tabular}

of 'Hamlin' and 'Valencia' trees to weather data and crop load status are presented in Tables 3 and 4, respectively. Cumulative temperature data, in the form of the total number of hours in ranges of $5^{\circ} \mathrm{C}$ increments, were independent variables (Table 1).

For both cultivars, flowering buds per shoot increased with greater number of hours in the 11 to $15^{\circ} \mathrm{C}$ temperature range and decreased in the presence of fruit. In the case of 'Valencia', flowering buds per shoot decreased with increased number of hours above $30{ }^{\circ} \mathrm{C}$. When all the data is taken into consideration, the resulting equations accounted for $78.6 \%$ and $87.7 \%$ of the variability of flowering buds per shoot for 'Hamlin' and 'Valencia', respectively. When the controls were not included in the data set, the resulting equations accounted for $70.0 \%$ and $85.3 \%$ of the variability, and the significant variables remained the same.
The development of flowers per flowering bud of both cultivars was associated with more hours at 11 to $15^{\circ} \mathrm{C}$ and was inhibited by the presence of fruit. The resulting equations accounted for $18.1 \%$ and $62.1 \%$ of the variability for 'Hamlin' and 'Valencia' branches, respectively. Multiple regression analyses without the controls did not yield any temperature range as significant for 'Hamlin' and was only able to explain $10.8 \%$ of the variability of flowers per flowering bud. For 'Valencia', 11 to $15^{\circ} \mathrm{C}$ remained significant and other ranges $\left(6\right.$ to $10^{\circ} \mathrm{C}$ and 21 to $25^{\circ} \mathrm{C}$ ) also became significant. The presence of fruit had a significant inhibitory effect on the development of flowers per flowering bud when the analyses were performed without the controls.

For both cultivars, the development of flowers per shoot was associated with an increase in the number of hours at 11 to $15^{\circ} \mathrm{C}$ and 
was inhibited by the presence of fruit. In addition, for 'Valencia', hours in the 26 to $30^{\circ} \mathrm{C}$ were associated with a decrease in the number of flowers per shoot. The resulting equations accounted for $73.1 \%$ of the variability in the number of flowers per shoot of 'Hamlin' branches and $84.1 \%$ for 'Valencia'. When the controls were not considered in the analyses, other ranges became significant, and the resulting equations accounted for $70.5 \%$ and $83.3 \%$ of the variability.

\section{Discussion}

EFFECT OF SHOOT AGE (SUMMER VS. SPRING) ON FLORAL DISTRIBUTION. Shoot age had a significant effect on floral development of both cultivars. For an equal number of shoots, more flowers developed on buds from summer shoots in comparison with spring shoots. Therefore, when comparing buds from summer and spring flushes of growth of the same year, buds from previous summer are more easily induced than spring buds. These results agree with previous studies that report that an older shoot is less likely to have induction of floral buds than a younger shoot (Guardiola, 1981; Krajewski and Rabe, 1995; Moss, 1973b). This response suggests that the contribution of spring and summer shoots to total flowering may vary with inductive conditions and is influenced by the ratio of spring to summer buds. Personal observations by the authors (data being collected) indicate that more spring than summer shoots occur in a tree. The proportion of spring to summer flush probably differs depending on the growing conditions and the extent of flowering in the previous year and location. An important aspect that was not evaluated in this study is the proportion of the flowers on spring and summer shoots that set fruit. In both cultivars, floral distribution by position along the shoot showed a marked apical tendency regardless of shoot age. In all situations, the majority of the flowers were located at or near the apex of the shoot (Positions 1 through 3 ), and decreased gradually towards more basal positions. Fewer flower buds developed in spring shoots, and flower development in more basal buds of spring shoots was negligible. Whether bud age, shoot age or bud position through some apical influence are the primary internal determinants of potential flowering levels interacting with environmental induction needs further evaluation.

EFFECTS OF INDUCTION LEVELS AND CROP LOAD TREATMENTS ON PHENOLOGICAL RESPONSE. Low temperature inductive conditions resulted in the transition of buds from vegetative to reproductive. Vegetative buds were thus reduced in favor of reproductive buds under low temperature inductive conditions (data not shown, see Valiente, 2001).

Floral intensity (flowers per shoot) was significantly increased as induction levels increased through the winter. In accordance with previous reports from California (Furr and Armstrong, 1956) and Israel (Ayalon and Monselise, 1960; Monselise and Halevy, 1964), the most intense flowering occurred at the highest induction levels (later in winter). In our study, increased floral intensity was primarily attributed to increased number of reproductive buds per shoot. However, greater induction levels generally caused more flowers per inflorescence also. In 'Hamlin', some buds that had been exposed to lesser amount of inductive conditions developed more flowers than those exposed to more inductive conditions. The reasons for these differences in bud response are not clear. They could still be by chance. If real, this effect may be related to conditions at the moment of bud sprouting and could have been related to hormonal or root growth changes caused by fruit maturity. The harvests of the 'Hamlin' crop during the inductive periods were conducted after the dates on which these anomaly events occurred each year.
As induction levels increased, crop load had a significant effect in the development of flowers per shoot for both cultivars and seasons. The presence of fruit reduced the magnitude of the flowering response by an average of $41.5 \%$. Crop load may reduce the sensitivity of the buds to inductive conditions, or more inductive conditions may be needed to overcome the inhibiting effect of fruit on floral induction. The effects of crop load on citrus flowering may be related to carbohydrate and/or hormonal interactions. Although there is evidence that crop load enhances the photosynthetic rates of bearing trees (Lenz, 1978), crop load may also act as a strong sink for carbohydrates, which can reduce the flowering potential (Goldschmidt and Golomb, 1982). Gibberellin content is significantly higher in the leaves on fruit bearing shoots than in shoots without fruit (Koshita et al., 1999). According to Erner (1988), gibberellins and carbohydrates operate as independent regulatory factors in the flowering of citrus. In this study, only none or normal crop per branch was tested. The effect on flowering intensity of a small, medium, or large fruit load on large branches should be determined under field conditions to represent natural year-to-year variations in crop load.

EFFECT OF WEATHER ON THE PHENOLOGICAL RESPONSE OF 'VALENCIA' AND 'HAMLIN' TREES. In agreement with other studies for subtropical areas (Bellows and Morse, 1986; Ben Mechlia and Carroll, 1989; Lovatt et al., 1984), temperature was the most important environmental condition affecting citrus reproductive response. Moss (1969), using controlled temperatures to affect flower induction, demonstrated that temperatures below $20{ }^{\circ} \mathrm{C}$ contribute to flower bud induction, and Garcia-Luis et al. (1992) presented data that suggested that temperatures below $5^{\circ} \mathrm{C}$ may not be effective. In this study, 11 to $15^{\circ} \mathrm{C}$ was consistently significant for nearly all flowering parameters of both cultivars (Tables 3 and 4). For 'Valencia' the effect of 11 to $15^{\circ} \mathrm{C}$ was significant for all flowering parameters. For 'Hamlin' the effect of 11 to $15^{\circ} \mathrm{C}$ was significant on flowering buds per shoot and flowers per shoot, but it was not significant on flowers per flowering bud. In this case, the significance level was at 0.12 (not shown).

The fact that only 11 to $15^{\circ} \mathrm{C}$ was consistently significant does not prevent the possibility of other temperature ranges having an effect on flower induction. Time at other ambient temperatures may have varied together with the hours at 11 to $15^{\circ} \mathrm{C}$ sufficiently to obscure the influence of other temperature ranges that affect flower bud induction. This was not tested.

Greater periods of time at 11 to $15^{\circ} \mathrm{C}$ increased floral intensity by the combined effect on the number of sprouting buds with reproductive growth and the number of flowers per flowering bud. The effects of temperature and crop load on number of flowers per inflorescence were weaker than the effects on the number of flowering buds per shoot. This weaker effect of flowers per bud may be because the amount of inductive temperature conditions in Florida are much lower than in a Mediterranean type climate, such as California, where six or more flowers per bud are common (Lord and Eckard, 1987) (Lord and Eckard, 1987). In the 2 years of this study, only 1151 and $1412 \mathrm{~h}$ below $20^{\circ} \mathrm{C}$ were accumulated by 10 Jan. (about when the last initiation of differentiation begins in Florida) (Abbott, 1935). Therefore, our study does not preclude the possibility that the effect of low temperatures on flowers per flowering bud is much more pronounced with more extended winter conditions.

Changes in the resulting multiple regression equations when the controls are dropped and in the comparison of the control branches to the flowering response at the highest induction levels tend to indicate that there is a possible inhibitory effect of girdling 
and defoliation on bud sprouting. While girdling and defoliation seem to decrease bud sprouting in the absence of fruit, this effect is not repeated when fruit are present. Fruit may "buffer" the effect of girdling and defoliation by supplying some hormonal or other factors.

With the availability of winter irrigation in Florida and the long periods of water stress required to produce significant numbers of flowers (Cassin et al., 1969), drought-induced flower buds would not be expected in this study nor in Florida's citrus industry in general. Indeed, rainfall levels were not statistically related to flowering intensity (data not shown).

Differences in reproductive response by cultivar could be seen when comparing the effects of high temperature and crop load on flowering. While high temperatures $\left(>26\right.$ or $\left.30^{\circ} \mathrm{C}\right)$ decreased reproductive response in 'Valencia', this effect was not repeated in 'Hamlin' trees unless the control treatment was removed from the regression analysis, and then only for flowers per shoot. As for crop load, the presence of fruit reduced reproductive buds and flowers per inflorescence of both cultivars. Crop load on 'Hamlin' branches seemed to have a stronger inhibitory effect on flower buds and flowers per shoot than in 'Valencia' branches. Both the slopes and partial $R^{2}$ values were higher for 'Hamlin'. Generally, 'Hamlin' trees bear more fruit per tree than 'Valencia' (Florida Agricultural Statistical Service, 1966-2002), but total fruit per tree was not specifically measured in this study. Crop load effects remained significant despite the facts that 'Hamlin' fruits were harvested midway through the girdling and defoliation treatment sequence, and that 'Valencia' fruits remained on the tree through the flowering period. Apparently, the effect of crop load on flowering was operative early in the induction process. Lower carbohydrates or higher levels of gibberellins have been discussed as possible causes of reduced flowering on fruiting branches (Goldschmidt et al., 1985).

These results provide some insight into the variability in flowering intensity that has been observed in Florida. Year to year variability in winter temperatures clearly influences how many buds are induced to flower buds and their number of flowers. Crop load is also an important factor in determining the level of flowering for any given amount of inductive temperatures. This information, coupled with the response of flower bud development to different temperatures (Valiente and Albrigo, 2002), provides the framework for an expert system that predicts flowering intensity and date of bloom for Florida citrus.

\section{Literature Cited}

Abbott, C.E. 1935. Blossom-bud differentiation in citrus trees. Amer. J. Bot. 22: 476-485.

Altman, A. and R. Goren. 1974. Growth and dormancy cycles in Citrus bud cultures and their hormonal control. Physiol. Plant. 30:240-245.

Ayalon, S. and S.P. Monselise. 1960. Flower bud induction and differentiation in the Shamouti orange. J. Amer. Soc. Hort. Sci. 75:216-221.

Bellows, T.S. and J.G. Morse. 1986. Modeling flower development in navel oranges. Sci. Hort. 30:117-126.

Ben Mechlia, B. and J.J. Carroll. 1989. Agroclimatic modeling for the simulation of phenology, yield and quality of crop production II. Citrus model implementation and verification. Intl. J. Biometeorol. 33:52-65.

Cassin, J., J. Bourdeaut, A. Fougue, V. Furon, J.P. Gaillard, J. LeBourdelles, G. Montagut, and C. Moreuil. 1969. The influence of climate upon blooming of citrus in tropical areas. Proc. 1st Intl. Citrus Symp. 1:315-323.

Davenport, T.L. 1990. Citrus flowering. Hort. Rev. 12:349-408.

Erner, Y. 1988. Effects of girdling on the differentiation of inflorescence types and fruit set in 'Shamouti' orange trees. Israel J. Bot. 37:173-180.

Florida Agricultural Statistical Service. 1966-2002. Citrus summary (published annually). Fla. Dept. Agr., U.S. Dept. Agr., Orlando.
Furr, J.R. and W.W. Armstrong. 1956. Flower induction in Marsh grapefruit in the Coachella Valley, Calif. Proc. Amer. Soc. Hort. Sci. 67:176-182.

Furr, J.R., W.C. Cooper, and P.C. Reece. 1947. An investigation of flower formation in adult and juvenile citrus trees. Amer. J. Bot. 33:1-8.

García-Luis, A., V. Almela, C. Monerri, M. Agusti, and J.L. Guardiola. 1986. Inhibition of flowering in vivo by existing fruits and applied growth regulators in Citrus unshiu. Physiol. Plant. 66:515-520.

García-Luis, A., F. Fornes, and J.L. Guardiola. 1995a. Leaf carbohydrates and flower formation in Citrus. J. Amer. Soc. Hort. Sci. 120:222-227.

García-Luis, A., M. Kanduser, and J.L. Guardiola. 1995b. The influence of fruiting on the bud sprouting and flower induction responses to chilling in Citrus. J. Hort. Sci. 70:817-825.

García-Luis, A., M. Kanduser, P. Santamarina, and J.L. Guardiola. 1992. Low temperature influence on flowering in Citrus. The separation of inductive and bud dormancy releasing effects. Physiol. Plant. 86:648-652.

Goldschmidt, E.E., N. Aschkenazi, Y. Herzano, A.A. Schaffer, and S.P. Monselise. 1985. A role for carbohydrate levels in the control of flowering in citrus. Scientia Hort. 26:159-166.

Goldschmidt, E.E. and A. Golomb. 1982. The carbohydrate balance of alternatebearing citrus trees and the significance of reserves for flowering and fruiting. J. Amer. Soc. Hort. Sci. 107:206-208.

Goldschmidt,E.E. and S.P. Monselise. 1972. Physiological assumptions towards the development of a citrus fruiting model. Proc. Intl. Soc. Citricult. 2:668-672.

Guardiola, J.L. 1981. Flower initiation and development in citrus. Proc. Intl. Soc. Citricult. 2:242-246.

Guardiola, J.L. 1997. Overview of flower bud induction, flowering and fruit set, p. 5-21. In: S.H. Futch and W.K. Kender (eds.). Citrus flowering and fruit short course. Citrus Res. Educ. Ctr., Lake Alfred, Fla.

Guardiola, J.L., M. Agusti, and F. Garcia-Mari. 1977. Gibberellic acid and flower bud development in sweet orange. Proc. Intl. Soc. Citricult. 2:696-699.

Koshita, Y., T. Takahara, T. Ogata, and A. Goto. 1999. Involvement of endogenous plant hormones (IAA, ABA, GAs) in leaves and flower bud formation of satsuma mandarin (Citrus unshiu Marc.). Scientia Hort. 79:185-194.

Krajewski, A.J. and E. Rabe. 1995. Bud age affects sprouting and flowering in Clementine mandarin (Citrus reticulata Blanco). HortScience 30:1366-1368.

Lenz, F. 1978. Photosynthesis and respiration of citrus as dependent upon fruit load. Proc. Intl. Soc. Citricult. 70-71.

Lomas, J. and P. Burd. 1983. Prediction of the commencement and duration of the flowering period of citrus. Agr. Meteorol. 28:387-396.

Lord, E.M. and K.J. Eckard. 1987. Shoot development in Citrus sinensis L. (Washington navel orange). II. Alteration of developmental fate of flowering shoots after $\mathrm{GA}_{3}$ treatment. Bot. Gaz. 148:17-22.

Lovatt, C.J., S.M. Streeter, T.C. Minter, N.V. O’Connell, D.L. Flaherty, M.W. Freeman, and P.B. Goodell. 1984. Phenology of flowering in Citrus sinensis [L.] Osbeck cv. Washington navel orange. Proc. Intl. Soc. Citricult. 1:186-190.

Monselise, S.P. and A.H. Halevy. 1964. Chemical inhibition and promotion of citrus flower bud induction. Proc. Amer. Soc. Hort. Sci. 84:141-146.

Moss, G.I. 1969. Influence of temperature and photoperiod on flower induction and inflorescence development in sweet orange (Citrus sinensis L. Osbeck). J. Hort. Sci. 44:311-320.

Moss, G.I. 1973a. The influence of temperature during flower development on the subsequent fruit-set of sweet orange (Citrus sinensis) 'Washington Navel.' Hort. Res. 13:65-73.

Moss, G.I. 1973b. Regrowth and flowering in sweet orange after pruning. Austral. J. Agr. Res. 24:101-109.

Moss, G.I. 1976. Temperature effects on flower initiation in sweet orange (Citrus sinensis L. Osbeck). Austral. J. Agr. Res. 27:399-407.

Poerwanto, R. and H. Inoue. 1990. Effects of air and soil temperatures on flower development and morphology of satsuma mandarin. J. Hort. Sci. 65:739-745.

Reuther, W., E.M. Nauer, and L. Summers. 1973. Effects of seasonal temperature regimes on development and maturation of citrus fruits. Proc. Intl. Soc. Citricult. 3:63-71.

Reuther, W. 1973. Climate and citrus behavior, p. 280-337. In: W. Reuther (ed.) The citrus industry. vol. 3. Univ. Calif. Press, Davis.

Simanton, W.A. 1969. Seasonal patterns of citrus bloom. Proc. Fla. State Hort. Soc. 82:96-98.

Tisserat, B., P.D. Galletta, and D. Jones. 1990. In vitro flowering from Citrus limon lateral buds. J. Plant Physiol. 136:56-60.

Valiente, J.I. 2001. Timing and intensity of flowering of sweet orange [Citrus sinensis (L.) Osbeck] as a function of local weather factors and crop under central Florida conditions. PhD diss. Univ. Fla.

Valiente, J.I. and L.G. Albrigo. 2002. Modeling flowering date of sweet orange [Citrus sinensis (L.) Osbeck] trees in Central Florida based on historical weather records. Proc. Intl. Soc. Citricult. IX Congr. 2000, 1:186-190. 